\title{
COMPARISON OF PROPELLER TYPE B-SERIES AND AU-OUTLINE GAWN SERIES FOR IMPROVING ON SUBMARINE PROPULSION PERFORMANCE USING CFD
}

\author{
Deddy Chrismianto, Ahmad Fauzan Zakki, Berlian Arswendo and Insanu Abdilla \\ Cendikia Abar \\ Department of Naval Architecture, Faculty of Engineering, \\ Diponegoro University Indonesia.
}

\begin{abstract}
Submarine propeller need some unique criteria can give bigger amount of thrust with noiseless. The submarine propeller design must able to produce the high thrust value, low pressure value, and smooth propeller streamline. This study investigates and compares some type of propeller that are $B-7$ series, $B-8$ series, Au - 7 Outline gawn series, and $A u-8$ outline gawn series with some different parameters, that is blade diameter, number of blades, skew angle and pitch. From some models that have been compared, the best propeller is B-8 series on $500 \mathrm{rpm}$ with thrust value $25481 \mathrm{~N}$, torque value $3927 \mathrm{Nm}$, average value pressure about 10608,92 Pa, and turbulance flow with average value velocity stream under $14,33 \mathrm{~m} / \mathrm{s}$.
\end{abstract}

Keywords: Submarine, B-series propeller, Au-series propeller, CFD.

Cite this Article: Deddy Chrismianto, Ahmad Fauzan Zakki, Berlian Arswendo and Insanu Abdilla Cendikia Abar, Comparison of Propeller Type B-Series and Au-Outline Gawn Series for Improving on Submarine Propulsion Performance using Cfd, International Journal of Advanced Research in Engineering and Technology, 10(2), 2019, pp. 647-651.

http://iaeme.com/Home/issue/IJARET?Volume=10\&Issue $=2$

\section{INTRODUCTION}

Submarine is a one of ship can dives independently. The submarine requirement with effective hull is designed for diving with long time under the sea, and it equipped by the periscope and torpedo for war [1]. Submarine propeller need some unique criteria in which the propeller can give bigger amount of thrust with noiseless for spying in submarine, so it has designed for moving without make noise or detected from other enemy radar and it can fast move under the water.

For the study purpose, the variable of parameters are choiced, that is; the number of blade, skew angle, diameter and blade type based on amount of effect that can reacted with propeller 
cavitation. The skew angle will make an effect on torque and thrust fluctuation in which it can increase the effect of propeller cavitation. The number of blade will effect on thrust fluctuation that cause thrust noise. Otherwise, the minimum number blade selected is about 7 for decrease the effect of turbulence for submarine propeller have limit for propeller diameter different with ordinary ship and the increase of diameter can make the decrease of propeller thrust and increase average of streamline speed $[2,3]$.

The purpose of this study is to obtain the comparation between thrust and torque values and streamline flow around propeller on several kind of the B-Series type propeller and $\mathrm{Au}$ - outline gawn series propeller type for applying on submarine.

\section{SUBMARINE PROPELLER}

Design and development of propellers for submarines are different from propellers for surface vessels. The most important demand is low acoustic signature that has priority over propeller efficiency, and the submarine propeller must be optimized with respect to acoustics rather than efficiency. Moreover, the operating conditions of a submarine propeller are quite different. These aspects are discussed as well as the weighing of the various propeller parameters against the design objectives $[4,5,6]$. That thing can cause the cavitation that can make some noise. The propeller may cause the cavitation in the highest speed that produce and lowest pressure on the propeller so it can make some steam bubble. That bubble mix with some other gas around and it cause cavitation flow [7]. From that cavitation flow cause noise that must avoid when we design a submarine propeller causes noise that must be avoid in design submarine propeller.

The propeller design process with CAD propeller software (Figure 1). After the coordinate data is obtained, so the surface data propeller is also found.
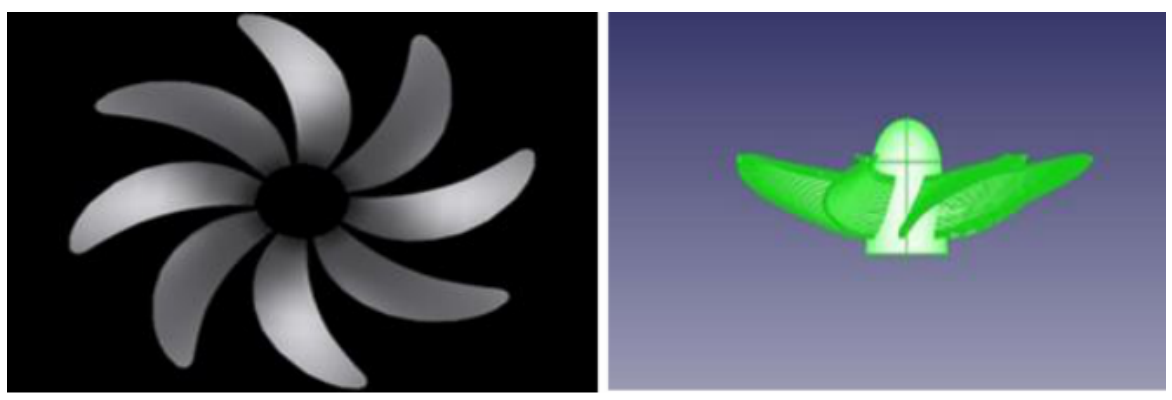

Figure 1 shows the submarine propeller model

\section{THEORETICAL ANALYSIS}

Each type of each ship's propeller has different performance curve characteristics. The study of the characteristics of a ship's propeller cannot be generalized to the overall shape or type of the propeller. The equation is as follows [8]:

$$
\begin{array}{r}
\mathrm{KT}=\frac{T}{\rho n 2 D 4} \\
\mathrm{KQ}=\frac{Q}{\rho n 2 D 4} \\
\mathrm{~J}=\frac{V a}{n x D}
\end{array}
$$

Where; $\mathrm{KT}=$ propeller thrust coefficient 
Comparison of Propeller Type B-Series and Au-Outline Gawn Series for Improving on Submarine Propulsion Performance using CFD

$\mathrm{KQ}=$ propeller torque coeffitcient

$\mathrm{J}=$ propeller advance coefficient

$\mathrm{Va}=$ advance velocity

$\mathrm{D}=$ propeller diameter

$\mathrm{n}=$ propeller rotation speed in $\mathrm{rpm}$

$\mathrm{T}=$ thrust propeller in $\mathrm{N}$

$\mathrm{Q}=$ torque propeller in $\mathrm{Nm}$

$\rho=$ fluid density

Thrust force is produced by the operation of the propeller is caused by a momentum difference that occurs when the propeller leaves move fluidized. The flow of water due to rotation the propeller in the water, then the reaction force will arise which is the force produced by the propeller leaves.

\section{RESULTS AND DISCUSSIONS}

Boundary condition for CFD calculation is generated with using propeller specification as follow:

- Propeller Diameter : $1,00 \mathrm{~m}$

- Blade Number : 7

- Pitch/diameter $: 1,03$

- Skew, Degree : $\quad$ : 30,8

Table 1 shows the result for validation between the experiment and the CFD calculation.

Table 1 Validation of Experiment result and CFD result at $500 \mathrm{rpm}$

\begin{tabular}{|c|c|c|c|}
\hline Rotation speed (rpm) & Experiment Result $\left(\mathbf{K}_{\mathrm{T}}\right)$ & CFD Result $\left(\mathbf{K}_{\mathrm{T}}\right)$ & Diff. (\%) \\
\hline 500 & 0.2594 & 0.2458 & 5.23 \\
\hline
\end{tabular}

Table 2 Thrust values on several types of propeller at $450 \mathrm{rpm}$ and $500 \mathrm{rpm}$

\begin{tabular}{|l|c|c|c|c|}
\hline & \multicolumn{4}{|c|}{ Propeller Type } \\
\hline & $\mathrm{Au}-8$ & $\mathrm{Au}-7$ & $\mathrm{~B}-8$ & $\mathrm{~B}-7$ \\
\hline Thrust at 450 rpm (N) & 23,683 & 11,723 & 203,47 & 21,009 \\
\hline Thrust at 500 rpm (N) & 27,742 & 11,967 & 25,481 & 22,436 \\
\hline
\end{tabular}

Table 3 Torque values on several types of propeller at $450 \mathrm{rpm}$ and $500 \mathrm{rpm}$

\begin{tabular}{|l|c|c|c|c|}
\hline & \multicolumn{4}{|c|}{ Propeller Type } \\
\hline & $\mathrm{Au}-8$ & $\mathrm{Au}-7$ & $\mathrm{~B}-8$ & $\mathrm{~B}-7$ \\
\hline Torque at $450 \mathrm{rpm}(\mathrm{N} \mathrm{m})$ & 3,532 & 2,001 & 2,975 & 3,063 \\
\hline Torque at $500 \mathrm{rpm}(\mathrm{N} \mathrm{m})$ & 4,330 & 2,153 & 3,927 & 3,543 \\
\hline
\end{tabular}

Table 2 shows the result of thrust analysis at $450 \mathrm{rpm}$ and $500 \mathrm{rpm}$ on several types of propeller. $\mathrm{Au}-8$ series propeller type has the highest thrust with $23683 \mathrm{~N}$ at $450 \mathrm{rpm}$ and also at $500 \mathrm{rpm}$ is obtained the highest thrust with $27,742 \mathrm{~N}$. While Table 3 shows the result of torque analysis at $450 \mathrm{rpm}$ and $500 \mathrm{rpm}$ on several types of propeller. $\mathrm{Au}-8$ series propeller type has the highest torque with $3,532 \mathrm{Nm}$ at $450 \mathrm{rpm}$ and also at $500 \mathrm{rpm}$ is obtained the highest torque with $4,330 \mathrm{Nm}$. 

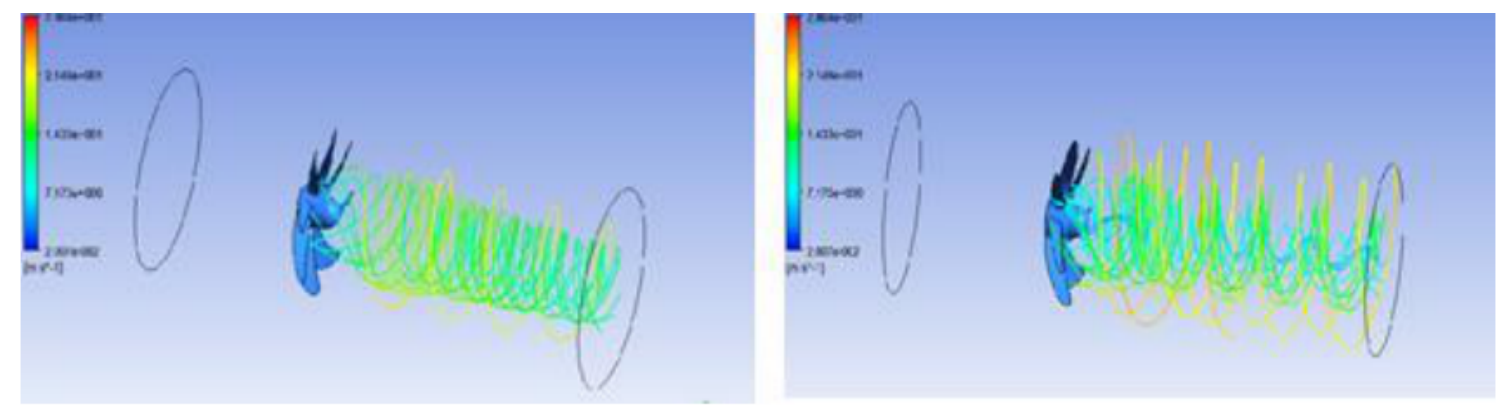

Figure 2 Streamline simulation $\mathrm{Au}-8$ and $\mathrm{Au}-7$
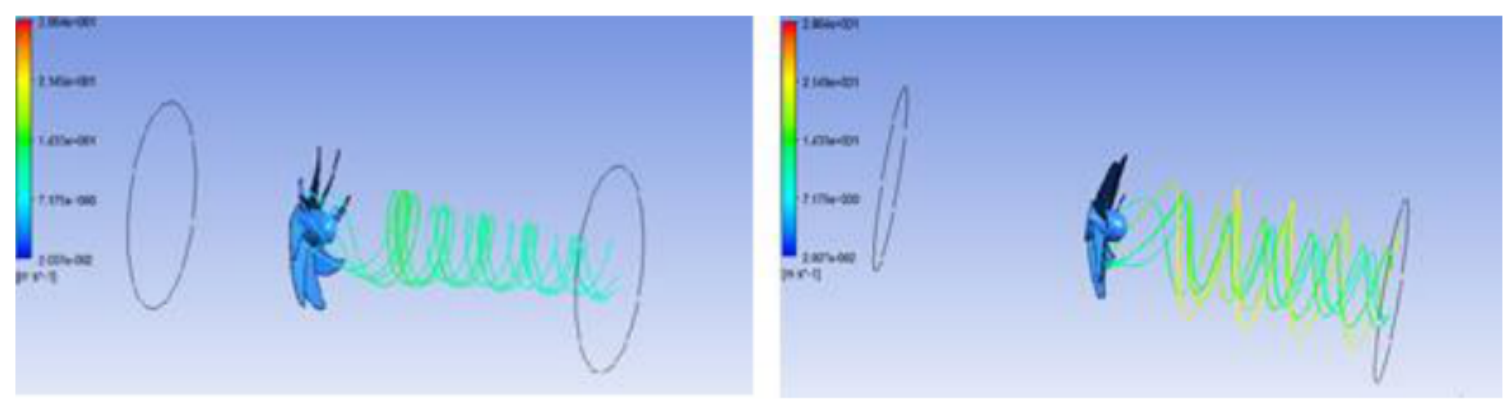

Figure 3 Streamline simulation $\mathrm{B}-8$ and $\mathrm{B}-7$
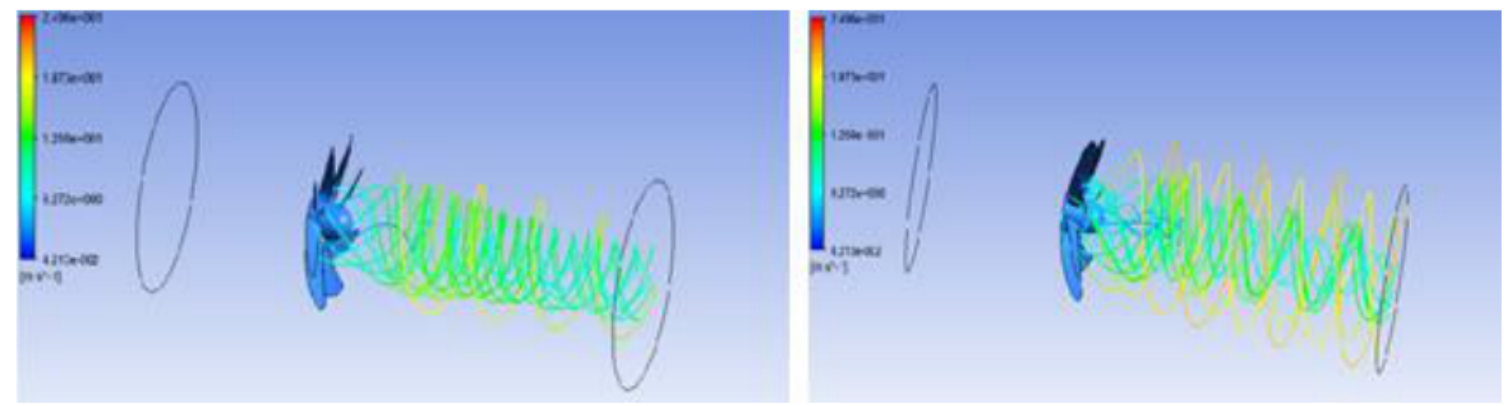

Figure 4 Streamline simulation $\mathrm{Au}-8$ and $\mathrm{Au}-7$

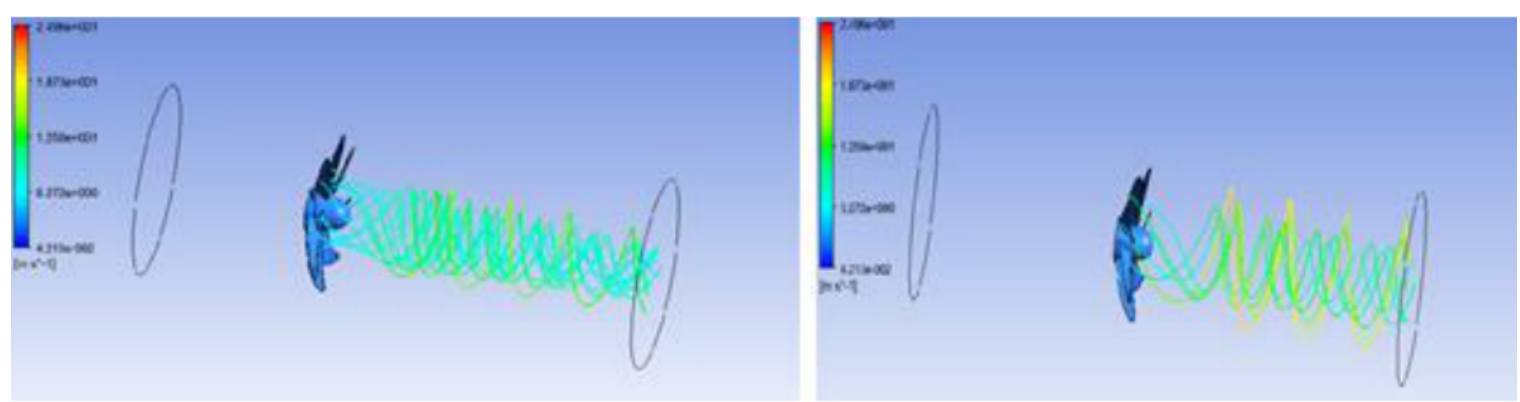

Figure 5 Streamline simulation $\mathrm{B}-8$ and $\mathrm{B}-7$

Figure 2 - figure 5 show the streamline comparison between four propeller type and be conclused that $\mathrm{B}-8$ Series is best streamline with average speed $14.33 \mathrm{~m} / \mathrm{s}$.

\section{CONCLUSION}

At $500 \mathrm{rpm}$, the propeller $\mathrm{Au}-7$ type produces a thrust $11,967 \mathrm{~N}$ at average pressure 87,231.83 $\mathrm{Pa}$ with average speed on streamline $16.05 \mathrm{~m} / \mathrm{s}$ but it has irregular flow. While the propeller $\mathrm{Au}$ -8 type produces a thrust $27,742 \mathrm{~N}$, average pressure $18,111.33 \mathrm{~Pa}$ with average speed on streamline $15.45 \mathrm{~m} / \mathrm{s}$ but has irregular flow. The propeller B -7 type is obtained a thrust 22,436 $\mathrm{N}$, average pressure 43,251.75 $\mathrm{Pa}$ with average speed on streamline $16.25 \mathrm{~m} / \mathrm{s}$ but has irregular 
Comparison of Propeller Type B-Series and Au-Outline Gawn Series for Improving on Submarine Propulsion Performance using CFD

flow. And the propeller B - 8 type has a thrust 25,481 N, average pressure 10,608.92 Pa with average speed on streamline $16.35 \mathrm{~m} / \mathrm{s}$ with smooth flow.

The chosen propeller is used on the Submarine of Midget Type $150 \mathrm{~m}$ is Propeller B -8 series type with thrust $25,481 \mathrm{~N}$, average pressure $10,608.92 \mathrm{~Pa}$, with average speed on streamline $16.35 \mathrm{~m} / \mathrm{s}$ with smooth streamline.

\section{ACKNOWLEDGEMENT}

Ministry of Research, Technology, and Higher Education, Republic of Indonesia in scheme of Penelitian Fundamental 2015.

\section{REFERENCES}

[1] Joulbert, P. N. Some Aspect of Submarine Design Part 1 Hydrodynamics, Australian Goverment. Australian: DSTO Platforms Sciences Laboratory, 2004, pp.45.

[2] Andersen, P., Kappel, J. J. and Spangenberg, E. Aspects of Propeller Developments for a Submarine, First International Symposium on Marine Propulsors. Norway, 2009, pp. 1-8.

[3] Chrismianto, D., Zakki, A. F., Arswendo, B. and Dong, J. K. Development of Cubic Bezier Curve and Curve-Plane Intersection Method for Parametric Submarine Hullform Design in order to Optimize the Hull Resistance by Using CFD. Journal of Marine Science and Application, 14(4), pp. 399-405.

[4] Abidin, Z., Chrismianto, D. and Trimulyono, A. Komparasi dan Analisa Underwater Thruster pada Remotely Operated Vehicle (ROV) dengan Metode CFD. Jurnal Teknik Perkapalan, 3(2), 2015, pp. 204-212.

[5] Chrismianto, D., Manik, P. and Good, R. Study Comparative of Stability Performance Between PVC Fishing Boat and Wooden Traditional Fishing Boat. IOP Conference Series: Materials Science and Engineering, 403(012002), 2018, pp. 1-6.

[6] Kiryanto, Ridwan, M., Adietya, B. A. And Chrismianto, D. Stability Analysis of Trawls Type Traditional Fishing Boat with Modification of Eco-Friendly Fishing Gear on the North Coast of Central Java. IOP Conference Series: Materials Science and Engineering, 403(012052), 2018, pp. 1-8.

[7] Trimulyono, A., Manik, P. and Huda, N. Analisa pengaruh Energy Saving Device pada Propeller dengan Metode CFD. KAPAL Jurnal Ilmu Pengetahuan dan Teknologi Kelautan, 10(3), 2013, pp. 147-153.

[8] Lewis, E. V. Principles of Naval Architecture Volume II: Resistance, Propulsion and Vibration, Second Revision. USA: The Society of Naval Architecture and Marine Engineers, 1988, pp. 181.

[9] Kibong Han, Yongtag Lee and Dongchan Shin, A Study on the Propeller Shaft of Car Using Carbon Composite Fiber for Light Weight, International Journal of Mechanical Engineering and Technology, 9(5), 2018, pp. 603-611

[10] Muhammad Harris Nubly and Hartono Yudo, Strength Analysis of Propeller Shafting on Orca Class Fisheries Inspection Boat Using Finite Element Method, International Journal of Civil Engineering and Technology, 8(10), 2017, pp. 1599-1610.

[11] Dr. S. Solomon Raj and Dr. P. Ravinder Reddy, Utilization of Bend Twist Coupling to improve the Performance of Hybrid Marine Composite Propeller, International Journal of Mechanical Engineering and Technology 9(3), 2018, pp. 443-449.

[12] Hartono Yudo, Aulia Windyandari and Ahmad Fauzan Zakki Numerical Investigation of the Buckling Strength Behavior of Ring Stiffened Submarine Pressure Hull. International Journal of Civil Engineering and Technology, 8(8), 2017, pp. 408-415. 